\title{
TRADISI MENGHAFAL AL-QUR'AN DALAM MASYARAKAT BENDA SIRAMPOG BREBES
}

\author{
Aisyah Zubaidah \\ Sekolah Tinggi Agama Islam Ki Ageng Pekalongan \\ iistamam@yahoo.co.id \\ Mutammam \\ Sekolah Tinggi Agama Islam Pekalongan \\ mutammamm@yahoo.com
}

\begin{abstract}
The tradition of memorizing the holy Quran cannot be separated from the people of Benda, Sirampog. For them, memorizing the holy Quran is a thariqoh (a particular way) to be a lofty man to get close to God (Allah). This tradition is inherited from family institution and teacher-student circle. This research shows that when this tradition creates a group of people who memorized Quran, the organization of Quran memorizer in one organization has a positive impact for their existence. Through this organization, they have a chance to develop a social and economic network to empower themselves. As a result, their opportunity to get a social and economic benefit is bigger than before. This research also found that, the power of a leader of this organization can support and facilitate the life of the tradition of Quran memorizer.
\end{abstract}

Keyword: tradition, Quran, Quran memorizer,

\section{Pendahuluan}

Desa Benda terletak di kecamatan Sirampog Brebes Jawa Tengah. Desa yang berlokasi dibawah kaki Gunung Slamet ini berbatasan dengan Desa Tonjong dan desa Kaliloka. Sementara di sebelah selatan bersebelahan dengan Desa Kaligua dan Kalilangkap. Sebelah barat bersebelahan dengan Bumiayu dan sebelah timur bersebelahan dengan Desa Plompong. Sebagai desa yang berlokasi di bawah kaki Gunung Slamet, Benda merupakan daerah dingin dengan tipikal tanah yang subur. Hasil pertanian yang jadi andalan desa ini adalah padi, dan sayur-sayuran.

Yang menarik dari desa Benda ini adalah, lebih kurang 100 orang warganya atau penduduk asli Benda adalah penghafal al-Qur'an. Jumlah tersebut meliputi warga yang tinggal di Benda ataupun yang sudah merantau baik bekerja atau melanjutkan pendidikan.
Demikian yang disampaikan Kiai Izzudin salah satu pengasuh pesantren alQur'an Benda sekaligus ketua Jamiyyah Al Qurra' wa Huffadz (kelompok komunitas penghafal al Qur'an) desa Benda kepada penulis. Penjelasan ini juga penulis saksikan sendiri ketika penulis tinggal selama dua tahun di desa Benda. Para penghafal al-Qur'an ini adalah mereka, perempuan dan laki-laki dari beragam usia yang, demi menjaga kekayaan hafalan yang mereka miliki, sehari-harinya selalu membaca al-Qur'an secara hafalan, baik secara sendiri-sendiri maupun berkelompok.

Sejarah Benda sebagai desa para penghafal al-Qur'an bila dirunut ke belakang berawal dari Kiai Suchaimi dan Kiai Kholil, dua kiai bersaudara dari Benda. Sepulang dari belajar di sejumlah pondok pesantren, pada awal dekade 1900-an, dua kiai tersebut bekerja sama melakukan gerakan santrinisasi penduduk 
desa setempat. Dalam satu dekade, gerakan yang mereka lakukan secara simpatik (meminjam istilah al-Qur'an: bil hikmah wal mau'idhah hasanah), berhasil mengubah penduduk Benda menjadi masyarakat yang mencintai al-Quran (http://www.alhikmahsatu.sch.id/profilsejarah-pondok-pesantren,).

Keberhasilan itu dapat dilihat dari, selain banyaknya penduduk yang menjadi penghafal al-Qur'an juga, maraknya kegiatan-kegiatan sosial masyarakat, yang melibatkan ritual pembacaan alQur'an secara hafalan (sima'an alQur'an), mulai dari pernikahan, khitanan, syukuran membangun rumah, kematian, dan lain-lain. Lebih-lebih dalam kegiatan keagamaan seperti hari-hari besar agama Islam, ritual sima'an al-Qur'an hampir selalu dimasukkan sebagai ritual pembuka atau puncak acara.

Semangat penduduk yang mencintai al-Quran ini menarik untuk dikaji. Merujuk pendapat Tylor (Coleman \& Watson, 1990: 13), semua hal yang meliputi pengetahuan, keyakinan, kebiasaan, kemampuan yang ditunjukkan seseorang sebagai anggota masyarakat di sebut sebagai tradisi. Dalam hal ini penulis memasukkan kebiasaan masyarakat Benda menghafal al-Qur' an ini juga sebagai sebuah tradisi. Tradisi yang bersifat warisan yang melekat erat dalam kehidupan masyarakatnya baik itu gagasan, tindakan dan hasil karya manusia (Kuntjoroningrat, 1996:3). Selanjutnya penulis akan mengurai tradisi menghafal al Qur'an di desa Benda ini dengan mengungkap siapa sebenarnya mereka, para penghafal al-Qur'an ini. Bagaimana mereka bisa memilih untuk menjadi penghafal al-Qur'an sebagai sebuah pilihan hidupnya, serta bagaimana menghafal al- Qur'an bisa menjadi tradisi yang langgeng yang tak bisa dipisahkan dari masyarakat desa Benda.

\section{Profil Para Penghafal al-Qur'an desa Benda \\ 2,1. Usia, Jenis Kelamin dan \\ Pendidikan}

Bagi masyarakat Benda, perjuangan dua Kiai bersaudara yaitu Kiai Suhaimi dan Kiai Kholil adalah berkah luar biasa bagi mereka. Masyarakat yang tadinya tidak mengenal al-Qur'an menjadi masyarakat yang mencintai al-Qur'an sampai melahirkan komunitas penghafal al-Qur'an 30 juz. Bahkan pada perkembangannya, masyarakat penghafal al-Qur'an Benda dewasa ini telah mencapai jumlah \pm 100 orang. Jumlah tersebut meliputi para penghafal alQur'an yang tinggal di Benda dan yang tinggal di luar daerah untuk bekerja dan kuliah di perguruan tinggi. Data lapangan penelitian ini hanya menemukan 55 orang penghafal al-Qur'an laki-laki dan perempuan yang tinggal menetap di Benda. Angket yang disebar untuk menjaring data diri penghafal al- Qur'an menunjukkan 42 dari 55 penghafal alQur'an yang tinggal di Benda adalah perempuan. Sedang sisanya, sebanyak 13 orang, adalah laki-laki.

Angket yang disebar juga berhasil menjaring informasi tentang usia mereka. Catatan mengenai usia para penghafal alQur'an perempuan merentang mulai dari yang paling tua 71 tahun sampai dengan yang paling muda berusia 22 tahun.. Sementara penghafal al-Qur'an laki-laki yang berhasil dicatat adalah paling tua 65 tahun dan paling muda 20 tahun. Jika dibuat tabel, maka usia para penghafal alQur'an laki-laki dan perempuan adalah sebagai berikut: 
Tabel 1. Usia para penghafal al-Qur'an Benda

\begin{tabular}{|c|c|c|c|c|c|c|c|}
\hline Jenis & Usia & Usia & Usia & Usia & usia & Usia & Jumlah \\
Kelamin & $20-29$ & $30-39$ & $40-49$ & $50-59$ & $60-69$ & $70-\ldots$ & \\
\hline Laki-laki & 4 org & 3 org & 3 org & 1 org & 2 org & 0 org & 13 org \\
\hline Perempuan & 11 org & 20 org & 5 org & 4 org & 1 org & 1 org & 42 org \\
\hline Jumlah & 15 org & 23 org & 8 org & 5 org & 3 org & 1 org & 55 org \\
\hline
\end{tabular}

Data mengenai pendidikan para penghafal al-Qur'an adalah sebagai berikut. Pendidikan terakhir yang dialami para penghafal al-Qur'an perempuan: tidak lulus SD 2 orang; lulus SD/SR/MI 5 orang; lulus MTs sebanyak 18 orang; lulus Madrasah Muallimat setingkat SLTA sebanyak 8 orang ; lulusan MA/SMA sebanyak 8 orang; dan lulusan S1/sarjana sebanyak 1 orang. Dari kalangan penghafal al-Qur'an laki-laki diperoleh data pendidikan sebagai berikut: lulus MI sebanyak 3 orang; lulus SMP 1 orang; lulus MTs sebanyak 2 orang; lulus Madrasah Muallimin setingkat SLTA sebanyak 1 orang; lulusan MA/SMA sebanyak 5 orang; dan lulusan S1/sarjana sebanyak 1 orang. Dengan demikian, tabelnya adalah sebagai berikut:

Tabel 2. Tingkat pendidikan para penghafal al-Qur'an Benda

\begin{tabular}{|c|c|c|c|c|c|c|}
\hline $\begin{array}{c}\text { Jenis } \\
\text { Kelamin }\end{array}$ & $\begin{array}{c}\text { Tidak } \\
\text { LulusSR } \\
\text { /SD/MI }\end{array}$ & $\begin{array}{c}\text { Lulus } \\
\text { SD/MI }\end{array}$ & $\begin{array}{c}\text { Lulus } \\
\text { SMP/MTs }\end{array}$ & $\begin{array}{c}\text { Lulus } \\
\text { SMA/MA/ } \\
\text { SMK }\end{array}$ & $\begin{array}{c}\text { Lulus } \\
\text { S1/Sarjana }\end{array}$ & Jumlah \\
\hline Laki-laki & & 3 org & 3 org & 6 org & 1 org & 13 org \\
\hline Perempuan & 2 org & 5 org & 18 org & 16 org & 1 org & 42 org \\
\hline Jumlah & 2 org & 8 org & 21 org & 22 org & 2 org & 55 org \\
\hline
\end{tabular}

\subsection{Tingkat Ekonomi}

Sebagaimana variabel tingkat usia dan tingkat pendidikan, variabel tingkat kemampuan ekonomi para penghafal qur'an di Benda juga beragam. Yang pertama adalah mereka yang kaya dan yang kedua mereka yang miskin dan sedang-sedang saja. Kelompok pertama jumlahnya tidak banyak, yakni mereka yang memiliki pesantren atau dari keluarga dekat pemilik pesantren. Bagi kelompok ini, kekayaan berasal dari keluarga dan dari posisi sosialnya sebagai pemilik pesantren. Seorang yang hafal alQur'an yang memiliki pesantren, tentu lebih sejahtera karena hadiah-hadiah yang diterimanya dari orangtua para santrinya dan tamu-tamu lain yang datang meminta jasanya. Lebih dari itu, para penghafal qur'an yang memiliki pesantren juga umumnya lebih sering mendapat undangan sima'an di luar daerah.

Sementara para penghafal al-Qur'an Benda yang tidak memiliki pesantren pada umumnya kemampuan ekonominya biasa-biasa saja. Sumber-sumber pendapatan ekonomi mereka peroleh melalui berdagang barang-barang keperluan santri, bertani, mengajar di sekolah di lingkungan pesantren, dan "amplop" dari undangan-undangan sima'an al Qur'an di luar daerah. Namun khusus yang terakhir, bersifat tidak menentu baik dalam jumlah maupun dalam frekuensi undangan yang mereka terima setiap bulannya. Bagi penghafal al-Qur'an yang hanya bisa mengajar hafalan al-Qur'an dan tidak memiliki sumber-sumber pendapatan ekonomi yang diperoleh dari keluarga, maka 
kemampuan ekonomi mereka sangat terbatas.

\subsection{Pemahaman Agama}

Sedangkan pemahaman agama para penghafal al-Qur'an Benda bervariasi, bergantung pada proses belajar yang pernah mereka jalani. Namun nampaknya, secara umum, pemahaman agama mereka terutama para penghafal qur'an perempuan, terbatas pada hal-hal yang berkait dengan al-Quran. Penjelasannya adalah, karena sebagian besar dari para penghafal al-Qur'an Benda adalah perempuan yang datang dari keluarga-keluarga biasa yang tidak mampu membiayai pendidikan tinggi anak-anaknya. Lagi pula, biasanya mereka belajar menjadi penghafal qur'an dengan menghafal di pesantren-pesantren di luar Benda pun hanya berproses melalui menghafal al-Qur'an. Hampir tidak ada penghafal qur'an perempuan yang menghafal sambil belajar ilmu-ilmu agama di luar yang berkaitan dengan ilmu al-Qur'an.

Berbeda dari para penghafal alQur'an perempuan, kalangan penghafal al-Qur'an laki-laki secara umum lebih berdaya dibanding temannya yang perempuan dalam hal pemahaman agama. Meski dari segi pendidikan mereka tidak berbeda jauh dari teman-teman mereka yang perempuan, para penghafal alQur'an laki-laki umumnya juga belajar kitab kuning pada saat mereka menjalani proses mesantren menghafal al-Qur'an. Salah satu sebabnya adalah, waktu yang mereka miliki lebih luas lantaran mereka tidak terganggu oleh masa-masa menstruasi.

Pemahaman keagaman pada diri para penghafal al-Qur'an nantinya berkait dengan peran dan status sosial yang mereka mainkan di tengah masyarakat. Jika beberapa penghafal al-Qur'an lakilaki adalah juga kiai yang mengajar ilmuilmu agama atau menjadi guru di sekolah, adalah karena mereka memiliki pemahaman agama lebih. Pemahaman tersebut diperoleh karena semasa belajar mereka memiliki waktu yang relatif lebih longgar dibanding para penghafal alQur'an perempuan untuk mengaji kitabkitab agama.

\subsection{Alasan Memilih Menjadi Penghafal al-Qur'an}

Keputusan memilih hidup menjadi penghafal al-Qur'an dibuat berdasar alasan yang bervariasi. Para penghafal alQur'an Benda pada umumnya memilih hidup menjadi penghafal qur'an karena cita-cita mereka sejak kecil, seperti yang dilakukan orangtua mereka atau anggota keluarga yang lain yang lebih tua. Di samping karena cita-cita, alasan lain menjadi penghafal al-Qur'an juga sering dilakukan karena pilihan hidup yang tidak disengaja sejak dari awal. Bentuk ini biasa terjadi pada mereka yangkarena alasan ekonomi-tidak bisa melanjutkan pendidikan di luar daerah, baik di pesantren maupun di perguruan tinggi, lalu memutuskan untuk menghafal al-Qur'an. Termasuk ke dalam alasan kedua ini, adalah kasus seseorang menjadi hafal al- Qur'an karena kakaknya yang tadinya dipersiapkan menja,di pengganti orangtuanya memimpin pesantren al-Qur'an, ternyata meninggal dalam usia muda. Alasan ketiga, yang bisa ditemukan dari data lapangan, adalah karena pengaruh dari guru atau kiai dan dari keluarga.Yang terakhir ditemukan juga alasan memilih hidup menjadi penghafal al-Qur'an karena potensi keuntungan sosial dan ekonomi yang mungkin diperoleh.

\section{5. Cita-cita dan Pilihan Hidup}

Cita-cita menjadi seorang penghafal al-Qur'an yang tertanam sejak kecil merupakan alasan paling kuat mengapa sejumlah orang Benda memutuskan memilih hidup menjadi penghafal al-Qur'an. Dari sejumlah 55 laki-laki dan perempuan penghafal al- 
Qur'an yang sempat peneliti temui, catatan lapangan kami menyebutkan 36 orang di antaranya mencita-citakan hafal al-Qur'an sejak kecil. Ahar (27 th) misalnya, saat menjelaskan mengapa dan bagaimana sampai ia menjadi penghafal al Qur'an, menuturkan:

"Saya memang tidak seperti teman-teman yang suka sekolah tinggi-tinggi. Cita-cita saya sejak kecil cuman ingin seperti kakek yang lanyah (lancar membaca hafalan) al-Qur'an. ... kakek orangnya sangat hebat. Beliau adalah al-Qur'an berjalan. Kalau ke Bumiayu ( $\pm 7 \mathrm{~km}$ dari Benda) kakek selalu sengaja berjalan kaki karena sambil nderes. Jika di sawah, sambil nyabuti rumput atau apa, mulutnya terus bergerakgerak membaca hafalan alQur'annya..."

Seperti secara umum dikenal di kalangan ahli antropologi bahwa nilai keyakinan dan pandangan hidup dalam keluarga berperan dalam proses pembentukan pandangan dan keyakinan seseorang termasuk didalamnya cita-cita seseorang (Ihromi, 1999:18). Nilai dan cara pandang seseorang diwariskan dari generasi ke generasi dalam suatu kelompok sosial (Ihromi, 199:19). Penelusuran terhadap latar belakang keagamaan keluarga Ahar membantu menjelaskan penafsiran kita mengapa ia sejak kecil telah bercita-cita menjadi penghafal al-Qur'an. Kakeknya adalah seorang penghafal al-Qur'an yang sangat lanyah (lancar hafalannya) yang tidak pernah lepas membaca al-Qur'an sampai digelari al-Qur'an berjalan. Pamannya bernama Warsa, guru al-Qur'an, juga seorang penghafal al-qur'an. Meski ibunya, yang ditinggal mati suaminya, bukan seorang penghafal al-Qur'an namun ia amat gemar membaca alQur'an sehingga dalam kondisi suci setiap seminggu khatam 30 juz. Ahar juga masih memiliki seorang bibi yang hafal al-Qur'an. Tumbuh dalam keluarga semacam itu, wajar jika kemudian Ahar mengagungkan dan mengidealkan manusia yang hafal al-Qur'an. Alih-alih dari melanjutkan belajar di sekolah atau madrasah yang lebih tinggi, setamat dari SMP Ahar justru berguru kepada dua guru al-Qur'an Benda, Warsa pamannya dan Abdul Karim , sampai tamat hafal 30 juz. Tidak cukup berguru di desanya, Ahar kemudian menambah pengalamannya berguru di pesantren khusus al-Qur'an di Brebes utara dan di Purwakarta Jawa Barat, sebelum akhirnya kembali ke Benda mengajar al-Qur'an dan menjadi imam mushalla.

Ahar bukan satu-satunya penghafal al-Qur'an Benda yang menjadi penghafal al-Qur'an karena memang sejak kecil telah mencita-citakannya . Umi Kulsum ( 26 th), seorang penghafal al-Quran perempuan berpredikat sarjana, adalah contoh lain. Ia berasal dari sebuah keluarga berpendidikan dan - untuk ukuran Benda - mapan secara ekonomi. Cita-citanya sejak kecil untuk hidup sebagai penghafal al-Qur'an tumbuh dan terus berkembang karena semua anggota keluarganya yang perempuan-mulai dari nenek, ibu dan kakaknya - adalah para penghafal al-Qur'an 30 juz. Ia menuturkan perjalanannya berproses menjadi seorang penghafal al-Qur'an:

Di Benda ini ke mana-mana ketemunya suara al-Qur'an. Sehabis shalat Maghrib, di ruang tamu keluarga-keluarga pada membaca al-Qur'an. Bahkan anggota keluarga yang tidak hafal pun tidak kalah dalam jumlah khatam membaca 30 juz alQur'an. ... setiap ada hajatan dan acara nishfu sya'ban ibu, nenek dan kakak saya yang perempuan selalu aktif berperan karena meraka adalah orang-orang yang hafal al-Qur'an. Saya pun ingin seperti mereka. ... meski baru 
menghafal secara serius tahun 2003, namun sejak kecil sambil sekolah dan kuliah saya terus menabung hafalan al-Qur'an.

Seperti dijelaskan di bagian paling awal dari artikel ini, proses santrinisasi yang dilakukan oleh Kiai Sukhaimi dan Kiai Kholil pada awal abad ke 20 telah berhasil mengubah masyarakat Benda menjadi masyarakat yang mencintai alQur'an. Manifestasi kecintaan tersebut berpuncak pada berkembangnya komunitas penghafal al Qur'an di sana. Pada tingkat awam, kecintaan kepada alQur'an di kalangan masyarakat Benda bisa ditemukan pada kegemaran mereka untuk membaca al-Qur'an secara rutin setiap hari. Hingga dewasa ini masih sangat mudah menemukan orang Benda bukan penghafal al-qur'an yang setiap seminggu sekali khatam al-Qur'an. Jika fakta ini kita baca menggunakan ungkapan Marx "ideas generate society and the society generates ideas," ( Morris, 2003: 24) maka semakin bisa dipahami pilihan Ahar, Umi Kulsum dan para penghafal al-Qur'a Benda lain yang sejak kecil telah memilih menjadi penghafal al-Qur'an sebagai jalan hidup mereka. Mereka hidup di tengah masyarakat yang cara berpikirnya dibentuk oleh pikiran-pikiran Kiai Kholil dan Kiai Sukheimi tentang masyarakat, maka wajar jika dalam proses selfbecoming mereka mematok cita-cita menjadi penghafal al-Qur'an karena masyarakat yang melahirkan mereka adalah masyarakat yang mengagungkan dan mengidealkan sosok penghafal alQur'an. Proses-proses pewarisan keyakinan dan nilai ini diwariskan secara menerus berikut proses imitasi dan identifikasi, pembelahan pengetahuan yang berjalan menjadikan pengidealan terhadap sosok penghafal al-Qur'an menjadi bersifat membumi (Baal, 1988:63, Fedyani, 1996:63).

\subsection{Pilihan Hidup yang Tidak Disengaja \\ Data lapangan menunjukkan} bahwa di kalangan penghafal al-Qur'an Benda, keputusan memilih hidup menjadi penghafal al-Qur'an bisa merupakan pilihan yang tidak disengaja sejak awal. Pilihan hidup, yang tidak disengaja sejak awal, ini banyak dilakukan para penghafal al-Qur'an Benda yang pada masa mereka berada dalam usia belajar, keluarga mereka tidak mampu menanggung biaya pendidikan. Tentang hal ini, seorang informan perempuan bernama Nurani (35 th) menjelaskan:

... Saya alhamdulillah dikaruniai kecerdasan, sehingga waktu sekolah di MI dan MTs dulu selalu mendapat ranking. Sayang karunia itu tidak disertai karunia lain berupa rejeki yang banyak di keluarga, sehingga sekolah saya mandek. ... teman-teman ke Jombang (untuk belajar di pesantren), saya di Benda saja menghafal dan setoran ke kiai Ahmad Asmuni .

Informan lain bernama Maryam, 26th, mengungkapkan hal yang kira-kira sama:

Jaman masih sekolah di Madrasah Aliyah dulu, saya suka membayangkan bisa kuliah di Jogja karena saya bercita-cita menjadi guru negeri. Namun apa daya kakak saya yang membiayai sekolah, hanyalah seorang tukang ojek. Lho, dari tidak dicita-citakan sekarang malah saya menjadi penghafal al Qur'an, seperti bu Nyai Milhah itu..

Faktor kemiskinan, sebagaimana sering diungkapkan para ahli ilmu sosial, hampir selalu menghambat korbannya untuk memperoleh akses ke pendidikan lebih tinggi dan kesehatan yang baik. Pengalihan dari cita-cita semula kepada 
pilihan menjadi penghafal al-Qur'an, bukan kepada alternatif lain, oleh sejumlah penghafal al-Qur'an Benda bisa terjadi karena sikap keberagamaan mereka yang sangat kental. Sementara itu, pandangan keagamaan mereka bersikap positif terhadap praktek-praktek penghafalan al-Qur'an. Hal ini sedikit banyak telah berperan memperkokoh keberlangsungan tradisi menjadi penghafal al Qur'an.

Namun jika dibaca dari sudut perspektif lain, gerakan pengalihan pilihan hidup menjadi penghafal alQur'an yang dilakukan karena problem kemiskinan justru bisa berujung pada melemahnya peran sosial dan penghormatan terhadap mereka. Penjelasannya adalah para penghafal alQur'an yang lemah secara ekonomi cenderung tidak memiliki ilmu dan keterampilan sosial pendukung yang cukup untuk bisa memainkan peran-peran sosial. Dalam kaitan ini, Mustakim 42th, seorang Kepala Madrasah di lingkungan pesantren di Benda menuturkan:

... penghormatan terhadap para penghafal al-Qur'an Benda oleh masyarakat Benda sendiri sudah tidak seperti dulu jaman saya kecil...Penghafal al-Qur'an yang hanya sekadar hafal tidak terlalu dihormati karena orang sekarang pinter-pinter dan wawasannya luas. Sedang mereka hanya bisa mengajar ngaji. .

Bentuk lain dari pilihan hidup yang disengaja sebagai alasan menjadi penghafal al-Qur;an terjadi dalam kasus Faishal laki-laki berusia 30 th. Orangtua Faishal memiliki pesantren khusus bagi santri putri penghafal al-Qur'an. Dalam keluarga, hanya Faishal seorang yang tidak hafal al-Qur'an; ayah (sudah meninggal), ibu, dua adik perempuan dan kakak laki-lakinya adalah para penghafal al-Qur'an. Ketika beberapa tahun lalu kakak laki-lakinya meninggal karena kecelakaan, Faishal yang lulusan pesantren tradisional tinggi dan sedang kuliah S1 memutuskan untuk beralih menghafal al-Qur'an karena harus ada yang menggati ayahnya memimpin pesantren tahfidz yang sedianya dilakukan oleh kakaknya.

\subsection{Dorongan Guru dan Keluarga}

Dalam forum focus group discussion (FGD) yang dihadiri 6 orang penghafal al-Qur'an dan 2 orang masyarakat bukan penghafal al-Qur'an mengatakan, mayoritas penghafal alQur'an Benda dewasa ini adalah hasil dorongan sekaligus bimbingan para kiai sebagai guru. Sihah, misalnya, menuturkan bahwa keputusannya untuk menghafal al-Qur'an sampai menjadi penghafal al-Quran seperti sekarang adalah berkat dorongan dua gurunya, kiai Ahmad Asmuni dan kiai Fatah. Janda berumur 65 tahun, sehari-hari berjualan beras dan kitab-kitab agama, tersebut berkisah:

Tahun 1982 umur saya sudah 40an tahun. Pikiran saya waktu itu, saya tak hendak menghafal 30 juz, cukup terus ikut ngaji bacaan saja setiap hari kepada kiai Ahmad dan kiai Fatah (perlu dijelaskan di sini, hingga dewasa ini orang-orang Benda yang bacaan al-Qur'an mereka sangat lancar sekalipun, setiap hari mereka masih terus mengaji mendemonstrasikan bacaan mereka satu per satu kepada para guru kiai di sana. peneliti). Namun kedua guru saya tersebut tidak henti-hentinya meyakinkan saya untuk sekalian menghafal al-Qur'an. ... beberapa tahun kemudian saya ikut diwisuda setelah berhasil khatam bil ghoib.

Dalam forum yang sama nyai Milhah, pengasuh pesantren al-Qur'an khusus putri, bercerita bahwa setamat dari belajar di Pesantren Krapyak, 
Yogyakarta, dirinya tidak bermaksud menghafal al Qur'an karena harus menikah dengan pemuda pilihan orangtuanya. Namun tanpa disangkasangka, orangtua dan suaminya mendorong dia untuk menghafal alQur'an dan mengirimnya ke Pesantren alQur'an Pandanaran di Yogyakarta.

...saya tidak membayangkan sebelumnya kalau saya, yang sudah berstatus sebagai istri orang, pada tahun 1977 kembali belajar di pesantren untuk menghafal alQur'an.

Dorongan keluarga sebagai alasan menjadi penghafal al-Qur'an juga muncul dari cerita Zaidah, perempuan berusia 32 th.

Tahun 1990-an kan tahun-tahun terjadi ledakan jumlah anak-anak Benda menghafal al-Qur'an di luar daerah. Sebagai guru ngaji ayah saya pengin ada anaknya yang hafal al Qur'an, maka saya dikirim ke kiai Mufid di Yogyakarta.

Sementara itu, dalam kasus Zaidah, dorongan keluarga bersifat efektif karena pada masa itu di Benda terjadi ledakan jumlah anak-anak muda untuk menghafal al-Qur'an. Tentang hal ini, Silah, 41 th, seorang guru negeri di Madrasah Aliyah di Benda, menuturkan kalau pada saat itu bukan hanya keluargakeluarga penghafal al-Qur'an saja yang berusaha menjadikan anak-anak mereka sebagai penghafal-penghafal al-Qur'an baru. Namun keluarga-keluarga bukan penghafal al-Qur'anpun menunjukkan minat cukup besar agar sebagian anakanak mereka, terutama yang perempuan, menjadi penghafal al-Qur'an. Kecenderungan baru ini berkembang setelah beberapa perempuan penghafal alQuran, anak-anak orang biasa beruntung mendapat jodoh orang kaya atau anak kiai dari luar daerah. Lebih jauh Silah, yang cucu seorang penghafal al -Qur'an dan keponakan kiai pemilik pesantren di Benda, mengatakan:

Hanum, anak seorang guru SD, adalah penghafal al-Qur'an perempuan Benda pertama yang mendapat jodoh orang kaya, pegawai bank di Jakarta. Keberuntungan Hanum disusul oleh anak perempuan Warsid, penjual air minum untuk santri, yang dinikahi anak seorang kiai pemilik pesantren di Kalimantan. Lalu haji Rohadi , petani, 2 anak perempuannya yang hafal alQur'an juga beruntung mendapat mertua keluarga terpandang dari Cirebon. Peristiwa-peristiwa ini menyebabkan para orangtua pada saat itu mempengaruhi anakanaknya untuk menjadi penghafal al-Qur'an karena berharap mendapat besan keluarga terhormat.

Silah bisa benar dan bisa pula salah dalam menafsirkan kecenderungan para orangtua di Benda dalam mendorong anak-anak perempuan mereka menjadi penghafal al-Qur'an sebagai akibat harapan dan cita-cita mendapatkan keuntungan sosial dan ekonomi. Faktanya, tidak lama setelah hafal alQur'an Zaidah yang disebut tadi dilamar dan dinikahi seorang pemilik pesantren dari tetangga Kabupaten.

\section{Pelestarian Tadisi Menghafal al- Qur'an}

\subsection{Regenerasi dalam Keluarga dan Lingkaran Guru Murid}

Regenerasi dalam keluarga merupakan rute paling efektif bagi keberlangsungan tradisi menjadi penghafal al-Qur'an. Dalam keluarga Mukrimah , 53th, misalnya, bisa ditemukan 8 anggota keluarga yang menjadi penghafal al-Qur'an ayah, 2 orang kakak, 2 orang adik, 2 orang anak serta seorang lain adalah Mukrimah 
sendiri. Dalam hampir setiap keluarga penghafal al-Qur'an, paling kurang terdapat satu orang lain yang juga menjadi penghafal al-Qur'an. Orang lain yang juga menjadi penghafal al-Qur'an tersebut bisa ayah, ibu, anak, kakak, adik, kakek atau nenek.

Di samping melalui rute keluarga, kontinuitas tradisi menjadi penghafal alQur'an juga terjadi melalui jalur lingkaran guru murid. Di sini yang dimaksud lingkaran guru murid adalah seperti dalam kasus Sihah yang telah disebut di atas. Sebagai tipikal orang Benda, sejak kecil hingga dewasa usia 40 tahun Sihah masih terus saja mengaji bacaan al-Qur'an ke 1 atau 2 orang kiai. Tentusaja, seperti teman-temannya yang mempertahankan kebiasaan mengaji ke guru selama puluhan tahun, sebelum memutuskan melangkah menjadi penghafal al-Qur'an. Sihah adalah orang yang sangat lancar membaca al-Qur'an. Meski begitu, Sihah tidak pernah benarbenar berminat menjadi seorang penghafal al-Qur'an sampai kemudian kiai Fatah, gurunya yang berusia lebih muda, meyakinkan Sihah untuk menghafal al-Qur'an menjadi penghafal al-Qur'an. Masih atas dorongan guru, Sihah menceritakan pengalamnnya:

Suatu hari saya yang beruntung di kelas pengajian ibu-ibu. Dalam lomba hafalan waktu itu, saya mendapat juara satu. Saya penasaran kok besar banget kotak hadiahnya. Begitu dibuka di rumah, eh ternyata hadiahnya garam. Ya, garam dapur! Wah, percaya atau tidak garam ternyata mampu membangkitkan semangat.

Cerita di atas menarik karena ia menjelaskan kepada kita bagaimana melalui cara-cara seperti itu, seorang kiai berhasil membangkitkan minat muridmurid yang tidak ada hubungan keluarga dengannya untuk masuk ke ikut dalam barisan para pengusung tradisi menjadi penghafal al-Qur'an.

Jika dilakukan kategorisasi, tradisi menjadi penghafal al Qur'an sebenarnya merupakan manifestasi dari sistem kepercayaan dan sistem nilai dalam suatu budaya yang berkembang pada masyarakat tertentu. Sebagai bagian dari sistem kepercayaan dan sistem nilai, tradisi menjadi penghafal al-Qur'an bersifat subyektif dan psikologis. Secara teoritik, sistem tradisi yang bersifat subyektif diwariskan dan dilestarikan melalui mekanisme gagasan atau psikologis yang bekerja "trough the human capacities of memory and communication" (Sztompka, 1993; hlm 57). Menggunakan mekanisme yang beroperasi melalui kapasitas mengingat dan mengomunikasikan ini, suatu masyarakat mewarisi sistem keyakinan, norma, nilai-nilai, pengetahuan dan simbol dari generasi sebelumnya. Pelaku-pelaku aktual dari proses pewarisan tradisi subyektif tersebut adalah keluarga, komunitas budaya, institusi pendidikan, organisasi agama, para ideolog dan bahkan juga negara.

Pandangan yang menghegemoni itu akan terus bertahan sepanjang secara resiprokal ia memberikan rasa aman, berkah ekonomi, pengakuan sosial dan kekuasaan bagi masyarakat di sana.

\section{2. Oorganisasi}

Kesadaran yang berkembang pada diri sejumlah tokoh Benda tersebut kemudian melahirkan prakarsa untuk mengembangkan paguyuban (asosiasi) para penghafal al-Qur'an Benda. Pada mulanya paguyuban tersebut bernama jamaah hafidz-hafidzah Benda. Namun karena secara nasional terdapat organisasi para penghafal al-Qur'an dan qari, maka kemudian diubah menjadi JQH (Jamiyyatul Qurra wal Huffadz) ranting Benda, mengikuti organisasi tingkat nasional. 
Langkah-langkah sejumlah tokoh Benda mengembangkan asosiasi para penghafal al-Qur'an sesungguhnya menjanjikan bagi kelangsungan tradisi menjadi penghafal al-Qur'an. Demikian, karena asosiasi-bentuk modern dari model komunitasnya Tonniesmelahirkan solidaritas di kalangan para anggotanya.

\section{3. Dukungan dan Fasilitasi Tokoh}

Dukungan dan fasilitasi tokoh merupakan faktor lain yang bersifat obyektif bagi keberlangsungan tradisi menghafal al-Qur'an. Yang dimaksud sebagai tokoh di sini adalah seorang kiai pemilik pesantren terbesar di lingkungan desa Benda bernama kiai Masruri Mughni. Sebagai cucu dari kiai Kholil, satu dari dua kiai paling awal Benda, kiai Masruri disebut-sebut sebagai tokoh bukan penghafal al-Qur'an yang paling serius melakukan upaya-upaya mempertahankan dan mengembangkan tradisi menghafal al-Qur'an. Ditanya mengapa dirinya sangat antusias terlibat dalam upaya-upaya melestarikan tradisi menghafal al-Qur'an, kiai Masruri menjelaskan keyakinannya bahwa suatu daerah yang para penghuninya berthariqah dengan thariqah al-Qur'an pasti menjadi daerah yang aman dan berkah. Dalam hal ini dia sepaham dengan dan terdorong oleh kerja-kerja rintisan kakeknya:

Kiai Masruri sendiri tidak dikenal sebagai kiai yang hafal al-Qur'an. Karena itu, untuk mewujudkan keyakinannya, kiai Masruri menitipkan beberapa anaknya kepada beberapa kiai Qur'an di Jogja dan Kudus untuk dididik menjadi penghafal al-Qur'an. Selain itu, paling tidak sekarang ia memiliki 2 orang menantu yang hafal al-Qur'an. Salah seorang anaknya yang hafal alQur'an dan beristrikan seorang penghafal al-Qur''an juga, sejak tahun 1995-an mengembangkan pesantren di Benda.
Di luar upaya-upaya melestarikan tradisi menghafal al-Qur'an yang melibatkan keluarganya secara langsung, kiai Masruri pada tahun 1970-an mengembangkan wadah yang disebutnya sebagai lembaga tahfidz. Lembaga ini merupakan sebuah pesantren tempat menghafal al-Qur'an yang diasuh secara kolektif oleh 5 orang kiai Qur'an Benda. Mereka adalah kiai Salafudin, paman kiai Masruri, kiai Aman, kiai Ahmad Asmuni, kiai Sayuti, dan kiai Fatah. Ke 5 kiai tersebut tetap tinggal di rumah masing-masing, namun setiap hari masing-masing dari mereka datang sesuai jadwal ke lembaga tahfidz untuk mengajar dan menerima setoran hafalan. Setelah membentuk dewan pengasuh, kiai Masruri menghubungi sejumlah orang kaya Benda meminta mereka masing-masing menjadi bapak asuh bagi sejumlah santri penghafal al-Qur'an di lembaga tahfidz yang didirikannya.

Di lingkungan Benda sendiri, kiai Masruri juga mengajak masyarakat untuk sering menggunakan jasa para penghafal al-Qur'an:

Saya selalu saja dalam berbagai forum pengajian rutin orang kampung, mendorong masyarakat untuk selalu mencari barakah Allah melalui khataman al-Qur'an. Baca sendiri setiap hari, jangan sampai kosong tiap bulannya dari khataman al-Qur'an. Kalau ada hajat apapun, pakailah itu para penghafal al-Qur'an untuk khataman. Jangan lupa amplopnya, seberapa pun. Karena dengan menghidupi para penghafal alQur'an, kita termasuk orang-orang yang melestarikan al-Qur'an.

\section{Penutup}

Tadisi menghafal al-Qur'an dalam masyarakat Benda ternyata memiliki ragam latar belakang motivasi pelakunya. Berdasar hasil penelitian yang berhasil didapat para penghafal al-Qur'an ini ada 
yang memilih menjadi penghafal alQur'an karena memang cita-cita hidup pelaku, kemudian ada juga karena keuntungan sosial dan ekonomi yang akan mereka peroleh, kebutuhan oleh masyarakat, serta dukungan dan fasilitasi pihak yang memiliki kekuasaan. Cita-cita hidup menjadi penghafal al Qur'an di kalangan masyarakat Benda berkembang karena keyakinan mereka bahwa "thoriqoh" yang paling tinggi untuk mencapai keridlaan Tuhan adalah alQur'an. Melalui basis ideologi "kecintaan kepada al-Qur'an dan kepada orangorang yang hafal al-Qur'an ini, kelangsungan tradisi menghafal al Qur'an terus berlanjut hingga sekarang.

Institusi keluarga dan lingkaran guru murid merupakan agen-agen yang bekerja aktif dalam proses pewarisan tradisi menghafal al-Qur'an menjadi penghafal al-Qur' an yang terjadi di Benda. Temuan ini memperkuat teori mekanisme pewarisan tradisi yang dikembangkan Tylor dan Sztompka bahwa tradisi diwariskan melalui berbagai agen, seperti keluarga dan sekolah.

Ketika tradisi menghafal al-Qur'an telah melahirkan komunitas penghafal alQur'an, maka pengorganisasian para penghafal al-Qur'an ke dalam satu wadah berpengaruh positif terhadap eksistensi mereka. Melalui pengorganisasian, para penghafal al-Qur'an memiliki kesempatan mengembangkan jaringan bagi pemberdayaan dan sebagai akibatnya peluang mendapatkan keuntungan sosial dan ekonomi pun menjadi besar. Satu lagi penelitian ini menemukan, kekuasaan yang berada di tangan tokoh bisa berfungsi sebagai penyangga dan fasilitasi bagi keberlangsungan tradisi menjadi penghafal al-Qur'an. Wallahu a'lam.

\section{Daftar Pustaka}

Abdullah, Irwan. 2006. Konstruksi dan Reproduksi Kebudayaan. Yogyakarta: Pustaka Pelajar.
Al Hikmah, Tim. 2015. el Waha Bulletin Al Hikmah 2 Benda Sirampog, Brebes.

Baal, J Vaan. 1988. Sejarah dan Pertumbuhan Teori Antropologi. Jakarta: Gramedia.

Coleman, Simon \& Helen Watson. 1990. An Introduction to Anthropolog. London: Quintet Publishing Limited.

Fedyani, Achmad. 1996. Logika Antropologi. Jakarta: Premadana Media Press.

Giddens, Anthony. 2005. Konsekuensikonsekuensi Modernitas. Yogyakarta: Kreasi Wacana.

Ihromi, T.O.(ed). 2006. Pokok-pokok Antropologi Budaya. Jakarta: Yayasan Obor Indonesia.

Koentjoroningrat. 1996. Pengantar Ilmu Antropologi. Jakarta: Rineke Cipta.

Morris, Brian. 2003. Antropologi Agama. Yogyakarta: AK Group.

Rojas, Róbinson. 1996. Modernization Theory and the Laws of Social Change. Diakses 24 Maret 2007 http://www.rrojasdatabank.org/capi tal8.htm.

Sztompka, Piötr. 2004. Sosiologi Perubahan Sosial. Jakarta: Prenada. http://www.alhikmahsatu.sch.id/pro fil-sejarah-pondok-pesantren. 